\title{
Miranda
}

Revue pluridisciplinaire du monde anglophone /

Multidisciplinary peer-reviewed journal on the English-

speaking world

15 | 2017

Lolita at 60 / Staging American Bodies

\section{Silvia Pellicer-Ortin, Eva Figes' Writings. A Journey through Trauma}

\section{Nathalie Vincent-Arnaud}

\section{OpenEdition}

\section{Journals}

\section{Electronic version}

URL: http://journals.openedition.org/miranda/10711

DOI: 10.4000/miranda.10711

ISSN: 2108-6559

Publisher

Université Toulouse - Jean Jaurès

\section{Electronic reference}

Nathalie Vincent-Arnaud, "Silvia Pellicer-Ortin, Eva Figes' Writings. A Journey through Trauma", Miranda

[Online], 15 | 2017, Online since 19 September 2017, connection on 16 February 2021. URL: http:// journals.openedition.org/miranda/10711 ; DOI: https://doi.org/10.4000/miranda.10711

This text was automatically generated on 16 February 2021.

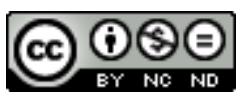

Miranda is licensed under a Creative Commons Attribution-NonCommercial-NoDerivatives 4.0 International License. 


\title{
Silvia Pellicer-Ortin, Eva Figes' Writings. A Journey through Trauma
}

\author{
Nathalie Vincent-Arnaud
}

\section{REFERENCES}

Pellicer-Ortin, Silvia, Eva Figes' Writings. A Journey through Trauma (Cambridge: Cambridge Scholars Publishing, 2015), 282 p, ISBN (10):1-4438-8062-0, ISBN (13): 978-1-4438-8062-6

1 Writing a monograph on such a confidential author as Eva Figes - whose name has long been hardly known - is certainly an exciting yet daunting task. Since Eva Figes passed away in London in late August 2012 (somewhat unnoticedly, as could be expected, in the academic world), and even before that, writing about her work has appeared to her devotees not only as a necessary tribute to a fine author but also as an attempt to shore substantial fragments against what may otherwise turn into ruins: her story, that of a traumatic experience which, as a matter of fact, tells us a lot about History, and particularly about one of the most dramatic episodes of the twentieth century, the Second World War and the Holocaust, and how people like her have had to wade through memories and remains to achieve some kind of self-identification. It is, therefore, Silvia Pellicer Ortin's major contention that what Eva Figes has left to us in terms of both literary and critical heritage can have a tremendous impact on one's conception not only of the power of words and literature, but also of how closely one may connect the experience of literature and the experience of living. History and literature, the world and the self are seen to merge in this multi-faceted work which can "tell contemporary readers and critics many things about human nature and the capacity to cope with individual and collective pain" (247).

2 The metaphor of the journey obviously reduplicates the strikingly echoing pattern of both Eva Figes' early novel Winter Journey (1967) and her ultimate 2008 memoir Journey to Nowhere (an echo which would, in itself, deserve a whole study as a process that 
seems to some extent to close upon itself while suggesting later investigations into what this nowhere may stand for). Along with the journey through Eva Figes' face suggested by the cubist-like front-cover illustration ${ }^{1}$, this metaphor is aptly used for the title of the book which is indeed an all-encompassing exploration - another central image $^{2}$-of the quest carried out by the author through the various experimental, testimonial, fictional and non fictional dimensions of her writings. As a distinguished specialist, fully aware of the subterranean logic of the work, Silvia Pellicer Ortin takes great care not to leave aside any single aspect of a substantial production which frames more than four decades; in doing so, she emphasizes how this multiplicity, ranging from experimental novels to sociological writings and autobiographical accounts, actually amounts to one single coherent whole which has its roots in an initial trauma, an essential divide.

As is detailed in Chapter 2, "Eva Figes' world", little Eva Figes (who was Eva Unger at that time) had to run away from Germany with her German-Jewish family at the outbreak of the Second World War and arrived in England - where she lived until her death - at the age of seven. Unlike lots of German-Jewish children who were part of the Kinderstransport to England where they found foster families-an episode recalled by such writers as poet Lotte Kramer-( Kindertransport, Before and After: Elegy and Celebration. Sixty Poems 1980-2007 [Brighton: University of Sussex, Centre for GermanJewish Studies, 2007]; New and Collected Poems [Ware: Rockingham Press, 2011]), Eva was lucky enough to leave Germany with her parents and brother but had to leave behind her grandparents who were soon to disappear in concentration camps. She also had, of course, to leave behind her mother tongue, as she keeps recalling in her autobiographical works: "Rule one: never speak German" (Little Eden. A Child at War [New York: Persea, 1978]). Eva Figes was to discover the truth about her grandparents' fate much later, at the age of thirteen, when her mother, unable to speak about the past herself, sent her to the cinema in London to find out about the horror of the Holocaust. Hence Eva Figes' enduring feeling that everything about her had been building up into a "conspiracy of silence", a phrase that she used in one of her late interviews (Ruth Gorb, "Fairy Tales Grimm and beautiful" [Camden New Journal, 20th March 2004 <http://www.camdennewjournal.co.uk]).

All that, of course, sets the stage for a particularly intricate relationship with language, since Eva Figes as a young girl is seen to have indeed lost her tongue twice (Tales of Innocence and Experience: An Exploration [London: Bloomsbury Publishing Plc, 2003] 122-123): first of all by being uprooted from Germany and having to fit into a new social and linguistic environment; second, by suddenly having to see through the smooth surface of the British social and linguistic reality she was living in and being taken back into a past she didn't know about because of her mother's obstinate silence which turned "'not knowing' into an art form" (Tales of Innocence and Experience: An Exploration 87). This redoubled linguistic and existential disruption is, of course, at the origin of a fragmented self, but it also paves the way for a paradoxical attitude towards writing, acutely brought to light in the late autobiographical works: on the one hand, writing means getting to grips with language in order to fight away silence, oblivion and suffering, while on the other hand, being rooted in what Eva Figes calls "the horror" (Tales of Innocence and Experience: An Exploration 122, 126, 173, 177) or "the dark pit" (Tales of Innocence and Experience: An Exploration 124), writing may be "tempted by silence" (George Steiner,. Language and Silence: Essays on Language, Literature, and the 
Inhuman [New York: Atheneum, 1967] 7) in the face of unspeakable truths as a reduplication of the fear-stricken and guilt-ridden mother.

Getting to grips with this dual perspective, Silvia Pellicer Ortin puts together the pieces of Eva Figes' writings just as Figes herself, in the first place, kept working through a series of fictional masks or doubles that she had to resort to as the primary stage of what can now be seen as "writing cure" or "scriptotherapy". This careful study is carried out along the lines of trauma studies-for which Silvia Pellicer Ortin provides a comprehensive and detailed framework before embarking on her analysis of the texts-, while the question of the literary material and influences is tackled from the complementary angles of the Modernist heritage and the ensueing experimental vein. Not experimental for experimentation's sake, but because a lot of the qualities inherited from Modernism, such as fragmentation and emphasis laid on various guises of stream of consciousness, were the ultimate outlet for anything genuine Eva Figes was able to come up with when she started her literary career. This was sometimes achieved in such a way as to excavate the very sound material of language, as one of her fictional characters does at the very beginning of her 1967 novel Winter Journey, a novel which is highly emblematic of this experimental phase and which is, significantly, one of her fictional works that have not-yet-been translated into French (nor into any language). As suggested by Silvia Pellicer Ortin, this difficulty to come to terms, even linguistically, with such writings echoes the "acting out of the trauma that is represented throughout the narration" (105), an attempt to return to the primary experience of language as a way of deciphering the world around and what the self, what identity, or at least identification is about. Writing is here equated with a whole territory of investigation to open up; it comes as no surprise, therefore, that Eva Figes should have quite often turned into a translator herself-a fact aptly enhanced by Silvia Pellicer Ortin(59)-, deeply concerned as she was with the specificities of each idiom and its ability to conjure up the strange or the familiar.

6 Just as the author's linguistic exile and sense of alienation are betrayed by her late memoirs, the fictional works throw further light on the tedious process of selfidentification: most of the characters are seen to have lost touch with the world outside and, first of all, with the anchoring, referential values of language. Passages from such early novels as Winter Journey or Konek Landing offer indeed striking examples of the character's desperate search for reliable landmarks, conveyed by a variety of streams of consciousness, fragmented or elliptic structures and blurred references. All these narrative devices are carefully explored by Silvia Pellicer Ortin, with an emphasis on symbolic patterns and intertextual echoes (to Virginia Woolf, Coleridge and, most significantly, T.S. Eliot). Even though the narrative itself is of a far less cryptic nature, a similar portrayal of disintegration is at work in the later novel Nelly's Version where the name of the main location, the Black Swan Hotel-hinting, of course, at a split personality-, but also the thresholds and the doorways that the whole novel is teeming with clearly indicate the character's confusion and sense of breaking apart. All that, of course, testifies to to the author's need to get into shape an enduring sense of void and to articulate "the identity conflict suffered by all women in patriarchal societies" (95).

7 In her last memoir, Journey to Nowhere, a challenging work which, as Silvia Pellicer Ortin underlines, "offers new alternatives to traditional autobiographical genres" (225), Eva Figes' political commitment went as far as taking a definite stand on Israel, as if to round off her survey of human alienation. All this does turn Eva Figes' works into a 
unified whole, consistent with the sense of the realities she had lived through (as an exile from the very start) and by (as an acute witness and observer of the suffering and changes she was confronted with all along). With its richly-documented and highly sensitive approach, including such treasurable first-hand material as an interview that she made with Eva Figes in 2009, Silvia Pellicer Ortin's book marks an important stage in the field of trauma studies while paying a fine tribute to an author who should be given prominence in the light of the various tensions, fears and mishaps of our century.

\section{NOTES}

1. Eva Figes' Portrait (2012), by Carlos Blanco Artero (https://http://www.carlosblancoartero.com/ blank-c786).

2. See the title of her 2003 memoir, Tales of Innocence and Experience. An Exploration.

\section{INDEX}

Keywords: experimental writing, Holocaust, identity, Modernism, scriptotherapy, testimony, trauma

Mots-clés: écriture expérimentale, Holocauste, identité, Modernisme, scriptothérapie, témoignage, trauma

\section{AUTHORS}

\section{NATHALIE VINCENT-ARNAUD}

Professeur

Université de Toulouse-Le Mirail

nathalie.vincent-arnaud@univ-tlse2.fr 